\title{
Simulated range of mid-Holocene precipitation changes to extended lakes and wetlands over North Africa
}

\author{
Nora Farina Specht ${ }^{1}$, Martin Claussen ${ }^{1,2}$, and Thomas Kleinen ${ }^{1}$ \\ ${ }^{1}$ Max Planck Institute for Meteorology, Bundesstrasse 53, 20146 Hamburg, Germany \\ ${ }^{2}$ Meteorological Institute, Centrum für Erdsystemforschung und Nachhaltigkeit (CEN), Universität Hamburg, Bundesstrasse \\ 55, 20146 Hamburg, Germany
}

Correspondence: Nora Specht (nora-farina.specht@mpimet.mpg.de)

\begin{abstract}
.
Enhanced summer insolation over North Africa induced a monsoon precipitation increase during the mid-Holocene, about 6000 years ago, and led to a widespread expansion of lakes and wetlands in the present-day Sahara. This expansion of lakes and wetlands is documented in paleoenvironmental sediment records, but the spatially sparse and often discontinuous sediment cords provide only a fragmentary picture. Former simulation studies prescribed either a small lake and wetland extent from reconstructions or focused on documented mega-lakes only to investigate their effect on the mid-Holocene climate. In contrast to these studies, we investigate the possible range of mid-Holocene precipitation changes in response to a small lake extent and a potential maximum lake and wetland extent.

Results show that the maximum lake and wetland extent shift the North African rain belt about $3^{\circ}$ farther northward than the small lake extent. Vegetated wetlands cause a larger precipitation increase than the equally-large lakes due to their high surface roughness. A moisture budget analysis reveals that both, lakes and wetlands, cause an enhanced inland moisture transport and local moisture recycling to their southern side. In contrast, increased moisture advection by the Harmattan winds causes a drying response to the north of the lakes and wetlands. These results indicate that the latitudinal position of the lakes and wetlands influences the northward extensions of the African summer monsoon. In the sensitivity experiments, the northern position of West Saharan lakes and wetlands substantially contributes to the strong monsoon northward shift seen in the maximum lake and wetland simulations.
\end{abstract}

\section{Introduction}

Paleoenvironmental sediment records reveal that North African lakes and wetlands spatially expanded during the mid-Holocene, as a result of increased summer monsoon precipitation (Holmes and Hoelzmann, 2017; Lézine et al., 2011). This precipitation increase was initiated by changes in the orbital forcing Kutzbach (1981), but reinforced by surface changes such as the expansion of vegetation (Kutzbach et al., 1996; Claussen and Gayler, 1997), the formation of soil (Levis et al., 2004; Vamborg 
et al., 2011) and the extent of lakes and wetlands (Coe and Bonan, 1997; Broström et al., 1998; Carrington et al., 2001; Krinner et al., 2012; Chandan and Peltier, 2020). Even though the extent of lakes and wetlands during the mid-Holocene is visible in sediment records, these records are spatially sparse and most of them are temporally discontinuous (Holmes and Hoelzmann, 2017; Lézine et al., 2011). Additionally, reconstructions widely differ regarding the existence of mega-lakes (Quade et al., 2018). Given this spatially and temporally limited information from reconstructions, investigating the effect of lakes and wetlands on the mid-Holocene climate becomes a scientific challenge.

Former simulation studies used different approaches to prescribe mid-Holocene lakes and wetlands to investigate their effect on the North African climate. The majority of these studies prescribed a small lake and wetland extent by Hoelzmann et al. (1998) that only considers mega-lake Chad (Broström et al., 1998; Carrington et al., 2001; Krinner et al., 2012). Results from these investigations show that a small lake and wetland extent only causes a marginal northward shift of the North African rain belt (Coe and Bonan, 1997; Broström et al., 1998; Carrington et al., 2001). A larger shift is caused, though, when this initial precipitation response is reinforced by vegetation feedback (Krinner et al., 2012). A more recent simulation study by Chandan and Peltier (2020) that considers several documented mega-lakes (e.g. Lake Ahnet, Chotts, Fezzan, Dafur and Chad) indicates that these large lakes only have a little impact on the northward penetration of the North African rain belt, but induce a precipitation increase over the Sahel region. These prior simulation studies all follow the approach of prescribing lakes and wetlands that are documented by reconstructions.

Comparison between dust emission simulations and marine sediment cores indicate that mid-Holocene lakes and wetlands might have expanded much stronger over the Western Sahara (Tegen et al., 2002; Egerer et al., 2018) than prescribed in any mid-Holocene simulations (Hoelzmann et al., 1998; Chandan and Peltier, 2020). Moreover, little research has been done regarding the role of vegetated wetlands during the mid-Holocene (Carrington et al., 2001). Present investigations on the effect of vegetated wetlands prescribed a small extent in the western Sahara and in the vicinity of mega-lake Chad (Carrington et al., 2001; Hoelzmann et al., 1998). Apart from mega-lake Chad, the existence of vegetated wetlands in the vicinity of other documented mega-lakes is also conceivable. In addition, vegetated wetlands may have formed as a result of seasonal flooding, as seen in the Okavango Delta in South Africa.

Thus, the limited availability in mid-Holocene sediment records entail interpretative uncertainties in the effect of lakes and wetlands on the mid-Holocene climate. Therefore, we investigate the possible range of mid-Holocene precipitation changes by exploring the effect of a small (Hoelzmann et al., 1998) and a potential maximum lake and wetland extent (Tegen et al., 2002), rather than following the approach of prescribing lakes and wetlands documented in reconstructions. This includes larger lakes and wetlands over the western Sahara, which might strongly affect the Saharan heat low and, thus, the West African monsoon precipitation itself.

\section{Methods}

In order to investigate the potential range of mid-Holocene precipitation changes induced by extended lakes and wetlands, we conduct four mid-Holocene sensitivity experiments. The sensitivity experiments are performed using the atmosphere model 
ICON-A (Giorgetta et al., 2018) and the land model JSBACH4 (Schneck et al., in preparation; Reick et al., 2021) at $160 \mathrm{~km}$ horizontal resolution and 47 vertical hybrid sigma level. This coupled atmosphere-land model is forced with climatological 6 kyr BP orbital parameters (Berger, 1978) and greenhouse gas concentrations (Brovkin et al., 2019). The climatological vegetation distribution is prescribed based on a 6 kyr BP MPI-ESM PMIP4-CMIP6 simulation (Brierley et al., 2020; Brown et al., 2020).

The ICON-ESM simulates regional sea-surface temperatures (SST) biases of up to $5 \mathrm{~K}$ (Jungclaus et al., in preparation), which causes a latitudinal displacement of the North African summer monsoon (Zhao et al., 2007). In order to simulate the latitudinal position of the North African summer monsoon in better agreement with proxy data, we use observation-based AMIP2 data to prescribe the SST and sea-ice concentration (SIC). The SST and SIC boundary conditions are derived as the following: monthly climatological differences between a 6 kyr BP and historical (1980-2014) MPI-ESM PMIP4-CMIP6 simulation are superimposed onto a AMIP2 climatology (1980-2014). To take into account the seasonal SST and SIC variability, transient monthly SST and SIC anomalies from the $6 \mathrm{kyr}$ BP simulation are added to the AMIP2-like mid-Holocene climatology.

Using this setup, the individual sensitivity experiments are run for 35 years, in which only the last 30 years are used as evaluation period. The individual sensitivity experiments differ only in their lake and wetland extent over North Africa: (1) 70 present lakes, (2) small lake extent, (3) maximum lake extent, (4) maximum wetland extent. In the control simulation, the present lake map for standard ICON AMIP2 simulations is used. The small lake extent is given by the reconstruction map from Hoelzmann et al. (1998) that is based on paleo-environmental records (Fig. 1a). The maximum lake extent is represented by the potential maximum lake extent simulated by Tegen et al. (2002) using the hydrological model HYDRA (Fig. 1b). The same potential maximum extent map is also used to prescribe the maximum extent of wetlands (Fig. 1b).
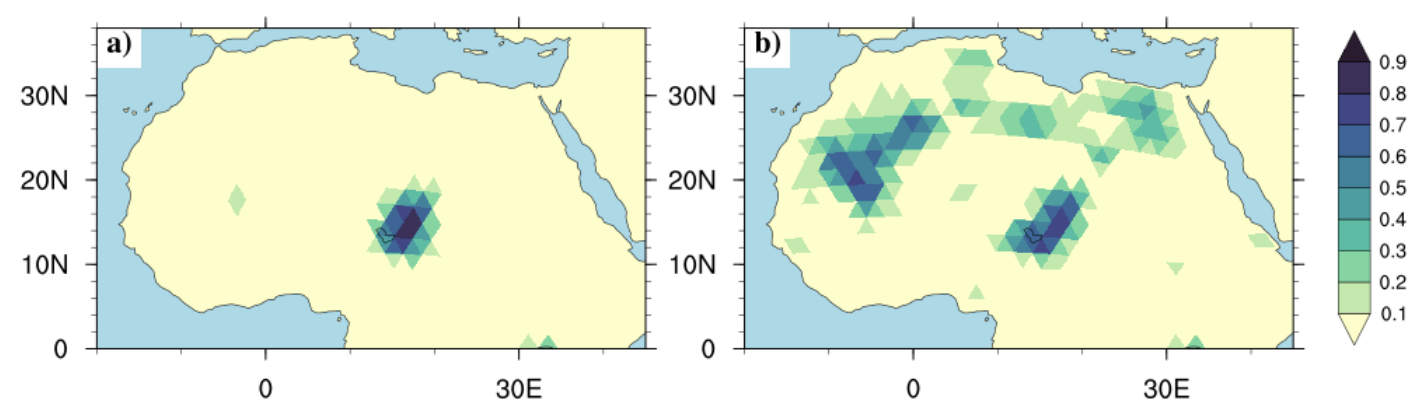

Figure 1. (a) mid-Holocene small lake fraction derived from paleoenvironmental reconstructions (Hoelzmann et al., 1998) and (b) midHolocene maximum lake fraction derived using the hydrological routing algorithm (HYDRA) (Tegen et al., 2002).

The lakes and wetlands are treated as fractional grid cell types in the land model JSBACH4. The lakes are represented by a simple constant-depth mixed-layer (10 m) approach (Roeckner et al., 2003). The surface temperature of the lakes is uniquely dependent on the net surface heat flux, and the lake albedo is set to a constant value of 0.07 (Roeckner et al., 2003). The wetland surface cover type was implemented into JSBACH4 for the purpose of this study and is defined as moisture saturated soil with an equal ratio of $\mathrm{C} 3$ and $\mathrm{C} 4$ grasses growing on it. This representation of wetlands is similar to the one used by Carrington 
et al. (2001). In contrast to lakes, wetlands have a higher surface roughness and a dynamic background albedo that depends on the vegetation's net primary productivity.

As indicated in the former section, the changes of the Saharan desert ground due to litter production from the vegetation is taken into account. Previous simulation studies showed that these changes in the background albedo (surface albedo without vegetation) substantially influence the mid-Holocene precipitation over the Sahel/Sahara region (Vamborg et al., 2011). To prescribe these background albedo changes, we use a parametrization scheme that is based on the concept by Egerer et al. (2018). The scheme by Egerer et al. (2018) prescribes the albedo changes of a mineral desert ground due to the dead biomass production from the vegetation growing on the desert ground and, thus, the formation of organic soil. The background albedo changes depend linearly on the net primary productivity (NPP) of the vegetation. The scheme by Egerer et al. (2018) neglects non-linear processes such as the overlapping of dead leaves and litter with increasing coverage of the ground with organic material. Therefore, we here use the following inverse exponential function to describe the background albedo changes during the mid-Holocene:

$\alpha_{\text {background }}=\alpha_{\text {mineral }}-\left(\alpha_{\text {mineral }}-\alpha_{\text {soil }}\right) \times e^{-\sum_{P F T}^{i=1} f_{i} \frac{\overline{N P P_{i}}}{N P P_{\text {soil }, i}}}$

$\alpha_{\text {background }}$ denotes the background albedo that depends on changes in the 5-year mean annual NPP $\overline{N P P} . N P P_{\text {soil }}$ represents the annual NPP needed to completely cover the ground with one layer of dead organic material (Egerer et al., 2018). $\alpha_{\text {mineral }}$ represents the mineral ground albedo and $\alpha_{\text {soil }}$ is the organic soil albedo reached, when the whole ground is covered with dead biomass (Egerer et al., 2018). alpha $a_{\text {soil }}$ is set to a mean value of 0.13 for the visible range and a mean value of 0.22 for the near-infrared range (Egerer et al., 2018). $\alpha_{\text {mineral }}$ is derived by inverting Eq. (1) and then calculating $\alpha_{\text {mineral }}$ for each grid cell using $\overline{N P P}$ from a standard AMIP ICON simulation and $\alpha_{\text {background }}$ obtained from MODIS observation data (Otto et al., 2011). Since the background albedo scheme prescribed the transition from a mineral dessert ground to a savanna landscape, this scheme is applied only in the North African Sahel-Sahara region $\left(10^{\circ} \mathrm{N}-35^{\circ} \mathrm{N} ; 20^{\circ} \mathrm{W}-35^{\circ} \mathrm{W}\right)$. Results reveal that the parametrization scheme is able to capture the relation between background albedo and NPP (not shown).

In order to investigate the precipitation response to the prescribed lakes and wetlands, the moisture budget response of the individual sensitivity experiments is analyzed. As prescribed by Seager et al. (2010), the moisture budget response is separated into a dynamic, a thermodynamic, a transient, a non-linear and a surface term. The results reveal which processes - beside the direct evaporation effect - mainly contribute to the precipitation changes in the individual sensitivity experiments.

\section{Results}

The maximum lake extent shifts the mid-Holocene African rain belt about $3^{\circ}$ farther northward than the small lake extent (Fig. 2). This precipitation difference is primarily caused by the increased evaporation over the western Sahara in the maximum lake experiment. The West Saharan lakes in the maximum lake experiment are located relatively far northward compared to the 
lakes in the small lake experiment (Fig. 1). These results indicate that the latitudinal position of the Saharan lakes likely plays a key role in shifting the simulated rain belt northward, particularly over the western Sahara where the African Easterly Jet is strongest and where the Saharan heat low is located.

Comparison between the maximum lake and wetlands experiment shows that replacing the lakes with vegetated wetland leads to an overall increase of the summer monsoon precipitation over North Africa (Fig. 2). This positive precipitation response to vegetated wetlands is associated with the high surface roughness. According to these results, regions where mega-lake were absent during the mid-Holocene, a seasonal flooding and formation of wetlands still might have strongly influenced the North African precipitation.

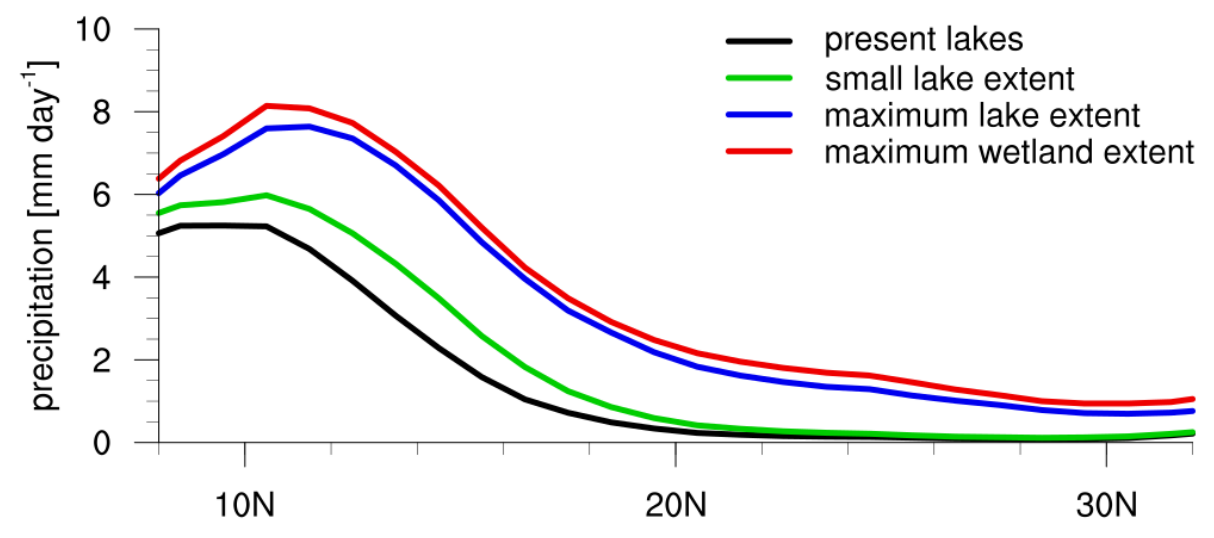

Figure 2. Mid-Holocene 30-year mean summer (JJAS) precipitation zonally averaged over Africa $\left(10{ }^{\circ} \mathrm{E}-30^{\circ} \mathrm{W}\right)$.

In order to better understand the influences of the lakes and wetlands on the mid-Holocene precipitation, changes in the moisture budget and changes in the atmospheric circulation are analyzed.

\subsection{Moisture budget response}

The moisture budget response $\delta(P-E)$ describes changes in the hydrological cycle that are caused by mechanisms other than the direct evaporation response induced by the lakes and wetlands (Seager et al., 2010). These hydrological changes can be separated into a dynamic response $\delta D Y$ induced by changes in the atmospheric circulation, a thermodynamic response $\delta T H$ induced by changes in specific humidity, and a mean $\delta N L$ and transient $\delta T E$ eddy response describing simultaneous changes in specific humidity and atmospheric circulation (Seager et al., 2010).

Results reveal that the prescribed lakes and wetlands cause a dipole-like moisture budget response $\delta(P-E)$ over North Africa, with a wetting response over the southern Sahara and a drying response over the northern Sahara (Fig. 4 a-c). The latitudinal position of the dipole-like response relates to the latitudinal position of the prescribed lakes. The line between wet and dry response reaches up to $20^{\circ} \mathrm{N}$ over the western Sahara in the maximum lake experiment and up to $15^{\circ} \mathrm{N}$ in the small lake experiment (Fig. 4 a-b). This north-south dipole-like response is primarily caused by dynamic and thermodynamic changes of the moisture budget (Fig. 4 d-i). Therefore, we only analyze the dynamic and thermodynamic response in detail. 


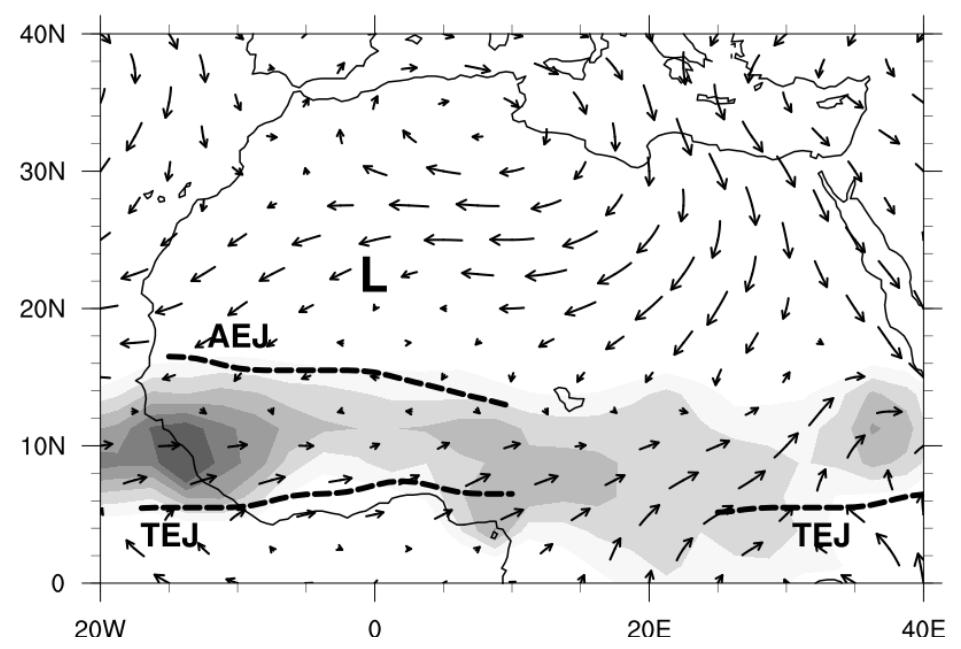

Figure 3. Schematic of African summer monsoon features for present conditions (1979-2020): the near-surface wind (monsoon south westerlies and Harmattan northeasterlies), the position of the Sahara heat low (L), the mid-troposphere African Easterly Jet (AEJ), the Tropical Easterly Jet (TEJ) and the rain belt region between both jets. The near-surface wind is given by the NCEP-DOE reanalysis 2 (Kanamitsu et al., 2002) and the precipitation is given by GPCP observations (Adler et al., 2003).

The dynamic response $\delta D Y$ indicates that enhanced monsoon westerlies induce an increased inland moisture transport to the south of the prescribed lakes and wetlands (Fig. 4 d-f). Over the Western Sahara, the maximum lakes induce an inland moisture transport that is much stronger and extends farther north than the inland moisture transport caused by the small lake extent (Fig. 4 d-e). The maximum lake and wetland extent, in contrast, cause a similar response pattern, but the wetlands induce a stronger response amplitude (Fig. 4 e-f). These result suggest that the position of West Saharan lakes and wetlands substantially influence the northward extent of the West African summer monsoon.

The thermodynamic response $\delta T H$ shows that moisture is locally recycled over the south-western Sahara, whereas moisture is advected away from the lakes and wetlands by the Harmattan winds over the north-eastern Sahara (Fig. 4 g-i; 3). Increased moisture recycling occurs in the uplift region of the North African rain belt that is associated with the southern track of the African Easterly Waves (Fig. 4 g-i; Fig. 3). Additionally, the West Saharan lakes and wetlands cause an even stronger moisture recycling at the northern track of the African Easterly Waves near the African West coast $\left(22^{\circ} \mathrm{N}\right)$ (Fig. 4 h-i). Over the southern Sahara, a warm and dry northeasterly Harmattan surface wind (Fig. 3) transports the moist air away from the lakes and wetlands during the summer season, which leads to a drying response over the northeast Sahara (Fig. 4 g-i).

The mean $\delta N L$ and transient eddy response $\delta T E$ causes a reversed and less pronounced dipole pattern compared to the dynamic and thermodynamic response (not shown). This dry-south wet-north dipole pattern is primarily associated with the northward shift of the ITCZ. This near surface convergence shift - in combination with the evaporation increase over North Africa - leads to the wet response over to the north and dry response to the south of the ITZC simulated in the control simulation. 

wetlands affect the summer monsoon circulation and precipitation in a similar way. To understand the mechanism that lead to the circulation changes indicated by the dynamic moisture budget response, the dynamic changes in the sensitivity experiments are analyzed.

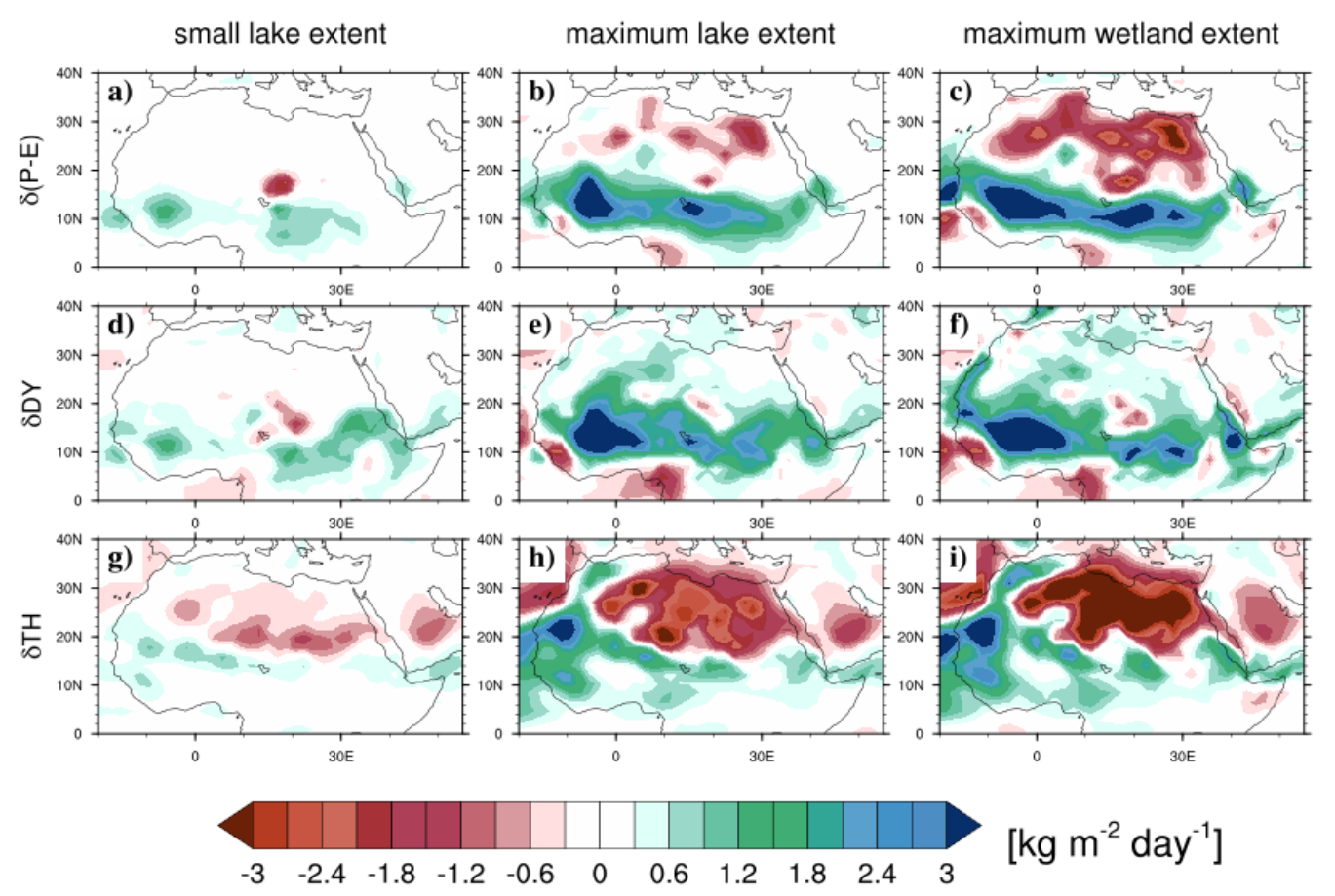

Figure 4. Mid-Holocene 30-year mean summer (JJAS) moisture budget response to a (left) small lake extent, (middle) maximum lake extent and (right) maximum wetland extent. Changes in the moisture budget (a-c: precipitation minus evaporation) are primarily caused by changes in the (d-f) dynamic component and thermodynamic component (g-f).

\subsection{Dynamic Response}

The zonal wind response shows that the lakes and wetlands cause a northward shift of the North African summer monsoon in all sensitivity experiment (Fig. 5). This northward extended monsoon is associated with a stronger Tropical Easterly Jet, a northward shift of the African Easterly Jet and stronger monsoon westerlies. These monsoon circulation changes are induced by the increased latent and decreased sensible heat flux over the lakes and wetlands (Fig. 6). These local turbulent heat flux changes induce a circulation response which is inverse to the one associated with the Saharan heat low.

The strong evaporative cooling effect of the lakes and wetlands leads to descending motions over the lakes and wetlands, which causes a high pressure response at the surface and a low pressure response aloft, at the mid-troposphere (Fig. 6). In the warmer vicinity of the lakes and wetlands, the moist air rises and converges again into the mid-troposphere low located 


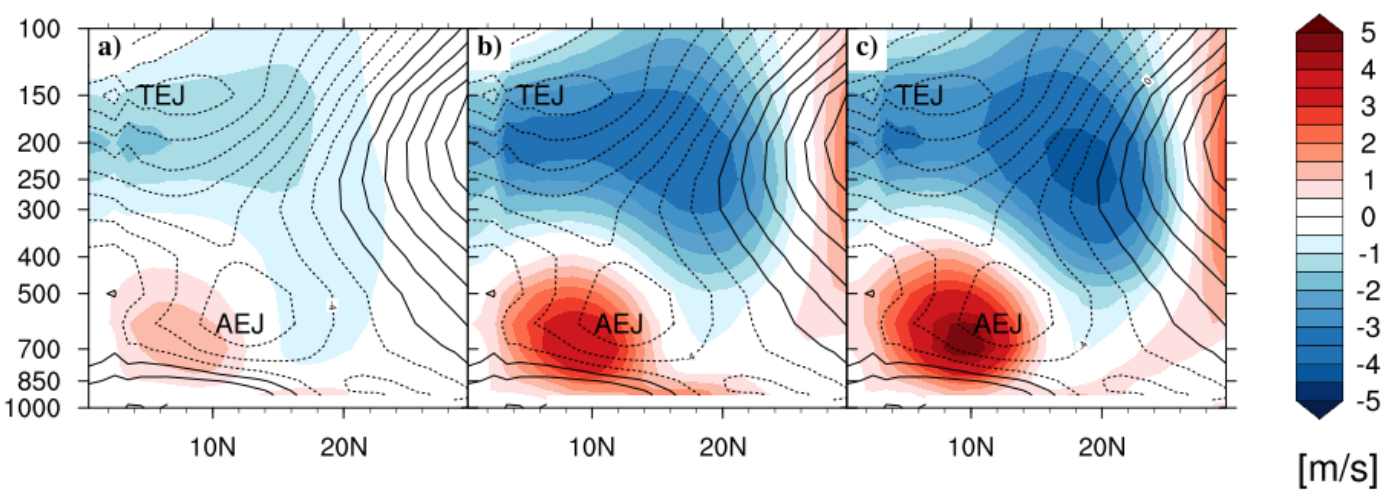

Figure 5. Mid-Holocene 30-year mean summer (JJAS) zonal wind response (colored shadings) to (a) the small lake extent, (b) the maximum lake extent and (c) the maximum wetland extent zonally averaged over North Africa $\left(10^{\circ} \mathrm{E}-30^{\circ} \mathrm{W}\right)$. Black contours show the mid-Holocene 30 -year mean summer (JJAS) zonal wind climatology zonally averaged over North Africa $\left(10^{\circ} \mathrm{E}-30^{\circ} \mathrm{W}\right)$.

above the lakes and wetlands. The resulting lower-level meridional overturning circulation causes, by Coriolis force, a westerly wind response to the south and an easterly wind response to the north of the mid-troposphere low (Fig. 5). This leads to the northward shift of the African Easterly Jet and strengthening of the monsoon westerlies shown in the zonal wind response (Fig.

5)

Additionally, the overturning circulation of moist air causes an increased moisture availability at the mid-troposphere low. This moisture convergence induces an increased moist convection in the mid- and upper troposphere above the lakes and wetlands (Fig. 6). The associated ascending motions and upper level divergence lead to a strengthening of the Tropical Easterly Jet (Fig. 5). This stronger Tropical Easterly Jet contributes to the northward shift of the North African monsoon system.

Beside these general circulation changes, the response amplitude and northward shift of the monsoon system substantially differs between the individual sensitivity experiments. Results show again that the stronger evaporation in the maximum wetland experiment compared to the maximum lake experiment causes a more pronounced monsoon circulation response (Fig. 5). Comparison between the small and maximum lake extent reveals that the West Saharan lakes induce a further northward shift of the monsoon system than Lake Chad (Fig. 6 a-b). These results are in accordance with the changes seen in the moisture budget.

\section{Discussion}

The precipitation response to the extended lakes and wetlands is probably reinforced by background albedo and evaporation feedback. The simulated rain belt northward shift of about $1.5^{\circ}$ in the small lake experiments is relatively large compared to the northward shift simulated by former studies that prescribe the same small lake extent (Broström et al., 1998; Carrington et al., 2001). Only the study by Krinner et al. (2012) shows an equally large northward shift in response to this small lake extent. In contrast to other studies, Krinner et al. (2012) use a dynamic vegetation that presumably reinforces the precipitation 

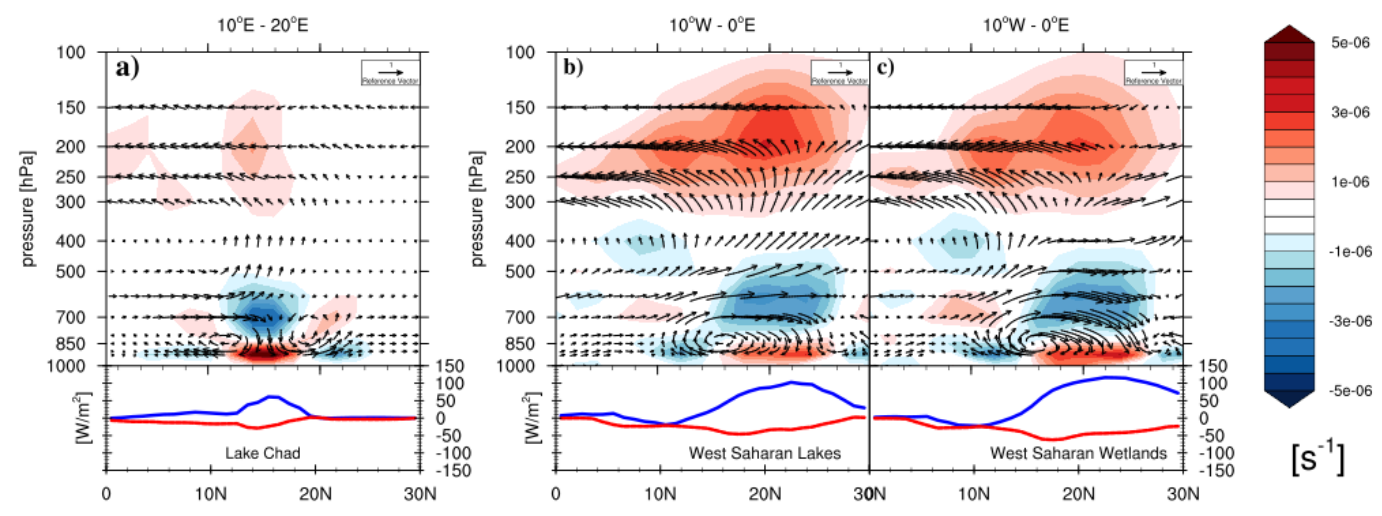

Figure 6. Mid-Holocene 30-year mean summer (JJAS) divergence response (colored shadings) to (a) the small lake extent (zonally averaged over the Chad region: $10^{\circ} \mathrm{E}-20^{\circ} \mathrm{E}$ ), (b) the maximum lake extent and (c) the maximum wetland extent (zonally averaged over the Western Sahara: $10^{\circ} \mathrm{W}-0{ }^{\circ} \mathrm{E}$ ). Black arrows show the mid-Holocene 30-year mean summer (JJAS) circulation response to (a) the small lake extent (zonally averaged over the Chad region: $10^{\circ} \mathrm{E}-20^{\circ} \mathrm{E}$ ), (b) the maximum lake extent and (c) the maximum wetland extent (zonally averaged over the Western Sahara: $10{ }^{\circ} \mathrm{W}-0{ }^{\circ} \mathrm{E}$ ). The bottom plots show the mid-Holocene 30-year mean summer (JJAS) (blue) latent and (red) sensible heat flux response to (a) the small lake extent (zonally averaged over the Chad region: $10^{\circ} \mathrm{E}-20^{\circ} \mathrm{E}$ ), (b) the maximum lake extent and (c) the maximum wetland extent (zonally averaged over the Western Sahara: $10^{\circ} \mathrm{W}-0{ }^{\circ} \mathrm{E}$ )

response to the prescribed lakes. Since the vegetation distribution is prescribed in our sensitivity experiments, this enhanced precipitation response likely results from changes in the background albedo due to the increased NPP from the vegetation. These albedo changes involve a positive evaporation feedback (Rachmayani et al., 2015).

In contrast to Chandan and Peltier (2020), our results indicate that the location of the lakes and wetlands influences the precipitation response of the North African summer monsoon substantially. This is particularly the case over the Western Sahara, where the African Easterly Jet is strongest and where Saharan heat low is located. In the study by Chandan and Peltier (2020) large lakes or wetlands are absent in the western Sahara. Instead lakes were distributed homogeneously over North Africa to investigate the potential effect of the lake position. Considering that lakes induce a strong moisture response to the northern and southern edge of the lakes, a broad homogeneous band of lakes over the Sahara would results in a positive precipitation response over the Sahel region.

Mid-Holocene reconstructions (Lézine et al., 2011) and transient mid-Holocene simulations (Dallmeyer et al., 2020) reveal that the African Humid Period ended earlier in the East Sahara than in the West Sahara. Reconstructions indicate that the maximum extent of mid-Holocene lakes lagged the peak of maximum summer insolation during the mid-Holocene (Lézine et al., 2011). According to our results, a widespread expansion of such persistent lakes over the western Sahara would have increased the West Saharan precipitation and, therefore, delayed the end of the African Humid Period in this region. 
We also speculate that west Saharan lakes and wetlands might have increased the autumn precipitation and, therefore, prolonged the rainfall season. A simulation study by Skinner and Poulsen (2016) shows that increased moisture availability throughout northern Africa during the mid-Holocene enhanced the formation of rainfall-producing tropical plumes over the western Sahara. Tropical plumes are elongated cloud bands that occur during the fall season as a result of extratropical-tropical interaction between an extratropical Atlantic trough and the Saharan heat low. Results by Dallmeyer et al. (2020) reveal that these rain bringing systems prolonged the mid-Holocene rainfall season and delayed the end of the African Humid Period over the western Sahara. Our results show that west Saharan lakes and wetlands push the North African rain belt northward, which would provide moisture for the formation of tropical plumes over the western Sahara. In our study we only focus on the monsoon summer season, but it is conceivable that West Saharan lakes and wetlands contributed to the formation of tropical plumes and, thus, prolonged mid-Holocene rainfall season and delayed end of the African Humid Period.

\section{Conclusions}

The prescribed lakes and wetlands all induce a northward shift of the North African rain belt. The maximum lake extent shifts the mid-Holocene rain belt about $3{ }^{\circ}$ farther northward than the small lake extent (Fig.5). This difference in the northward shift is mainly caused by the additional lakes over the western Sahara. The western Sahara represent a region where the African Easterly Jet is strongest and where the Saharan heat low is located (Fig. 3). The prescribed west Saharan lakes weaken the Saharan heat low and shift the monsoon system, including the African Easterly Jet, northward (Fig.5). This northward displacement of the monsoon relates to latitudinal position of the prescribed lakes. Based on our results, we conclude that the influence of the mid-Holocene lakes on the summer monsoon circulation is particularly strong over the western Sahara and that the latitudinal position of west Saharan lakes strongly influences the northward shift of the monsoon rain belt. Further on, results reveal that vegetated wetlands cause a stronger precipitation increase than equally-large lakes (Fig. 2). This strong precipitation response to vegetated wetlands is caused by a higher surface roughness.

Beside these differences, lakes and wetlands both affect the summer monsoon circulation and precipitation in a similar way. Lakes and wetlands induce a decrease in lower-level dry convection and increase in upper-level moist convection. The resulting descending motion in the lower troposphere and ascending motion in the upper troposphere causes a circulation response which is inverse to the one associated with the Saharan heat low (Fig. 6). The resulting mid-troposphere westerly wind response to the south and easterly wind response to the north of the lakes and wetlands pushes the African Easterly Jet northward and strengthens the near-surface monsoon westerlies (Fig. 5). This northward extension of the monsoon system affects the local moisture budget (precipitation minus evaporation) over the Sahara.

Analysis of the moisture budget show that the simulated precipitation increase in the sensitivity experiments is primarily caused by the evaporation from the lakes and wetlands. But enhanced inland moisture transports and a local moisture recycling to the south of the west Saharan lakes and lake Chad contribute to the simulated precipitation increase. This causes a wetting response over the southern Sahara (Fig. 4). Moisture advection by the Harmattan wind transport moisture away from the lakes and wetlands and causes a drying response over the northern Sahara (Fig. 4). This wet-south dry-north moisture budget response 
https://doi.org/10.5194/cp-2021-129

Preprint. Discussion started: 5 October 2021

(c) Author(s) 2021. CC BY 4.0 License.

(c) (1)

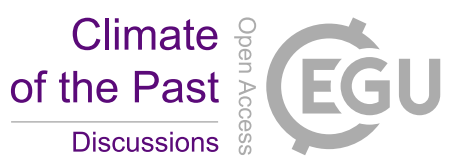

indicate that lakes and wetlands received access water primarily from the southern part of their catchment during the summer months. A simulation study by Skinner and Poulsen (2016) and Dallmeyer et al. (2020) showed that the enhanced occurrence of rain-bringing tropical plumes during the mid-Holocene fall season substantially increased the annual precipitation over the western Sahara. This indicates that West Saharan lakes and wetlands also received access water during the fall season.

In this study, we prescribe the vegetation, lakes and wetlands and, therefore, neglect their dynamic interaction. Investigating the dynamic interaction between the atmosphere, vegetation, wetlands and lakes would provide information about midHolocene climate changes and gives insights into the dynamic extent of lakes and wetlands during the mid-Holocene that are not provided by sediment records.

Data availability. The paleo-environmental lake reconstruction map by Hoelzmann et al. (1998) - used to prescribe a small lake extent - is accessible at the National Center for Environmental Information of the National Oceanic and Atmospheric Administration (https://www1. ncdc.noaa.gov/pub/data/paleo/pollen/africa6k). The potential maximum lake area - used to prescribe a maximum lake and wetland extent originates from the simulation study by Tegen et al. (2002). The potential maximum lake area data are accessible at T63 resolution at the German Climate Computing Center (https://cera-www.dkrz.de/WDCC/ui/cerasearch/entry?acronym=DKRZ_LTA_060_ds00002) and were provided by Egerer et al. (2018). For the purpose of this study the T63 reference data were interpolated to a R2B4 ICON grid.

Author contributions. NFS and MC planned the study. NFS developed the model components, ran the simulations and analyzed the results.

$\mathrm{MC}$ and TK contributed to the discussion of results and the manuscript.

Competing interests. The co-author Martin Claussen is editor at Climate of the Past. 
https://doi.org/10.5194/cp-2021-129

Preprint. Discussion started: 5 October 2021

(C) Author(s) 2021. CC BY 4.0 License.

(c) (1)

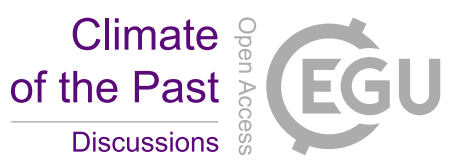

Acknowledgements. This study contributes to the Cluster of Excellence "Climate, Climate Change, and Society" (CLICCS), funded by the German Federation of Education and Research (BMBF). Nora Specht was financed by the International Max Planck Research School on 255 Earth System Modeling (IMPRS-ESM), Hamburg. The model simulation were performed at the German Climate Computing Center (DKRZ). Many thanks go to Reiner Schnur (MPI-M) for his excellent technical support, to Thomas Raddatz (MPI-M) for his comprehensive expertise and internal review, to Philipp Hoelzmann (FU-Berlin) for the helpful discussions and for providing the reconstruction data and to Ina Tegen for providing the model derived lake data.

The article processing charges for this open-access publication were covered by the Max Planck Society. 
https://doi.org/10.5194/cp-2021-129

Preprint. Discussion started: 5 October 2021

(c) Author(s) 2021. CC BY 4.0 License.

(c) (i)

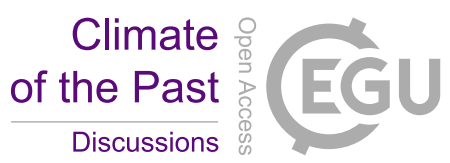

Adler, R. F., Huffman, G. J., Chang, A., Ferraro, R., Xie, P.-P., Janowiak, J., Rudolf, B., Schneider, U., Curtis, S., Bolvin, D., Gruber, A., Susskind, J., Arkin, P., and Nelkin, E.: The Version-2 Global Precipitation Climatology Project (GPCP) Monthly Precipitation Analysis (1979-Present), Journal of Hydrometeorology, 4, 1147-1167, https://doi.org/10.1175/1525-7541(2003)004<1147:TVGPCP>2.0.CO;2, https://journals.ametsoc.org/view/journals/hydr/4/6/1525-7541_2003_004_1147_tvgpcp_2_0_co_2.xml, publisher: American Meteorological Society Section: Journal of Hydrometeorology, 2003.

Berger, A.: Long-term variations of caloric insolation resulting from the earth's orbital elements, Quaternary Research, 9, 139-167, https://doi.org/10.1016/0033-5894(78)90064-9, http://www.sciencedirect.com/science/article/pii/0033589478900649, 1978.

Brierley, C. M., Zhao, A., Harrison, S. P., Braconnot, P., Williams, C. J. R., Thornalley, D. J. R., Shi, X., Peterschmitt, J.-Y., Ohgaito, R., Kaufman, D. S., Kageyama, M., Hargreaves, J. C., Erb, M. P., Emile-Geay, J., D’Agostino, R., Chandan, D., Carré, M., Bartlein, P. J., Zheng, W., Zhang, Z., Zhang, Q., Yang, H., Volodin, E. M., Tomas, R. A., Routson, C., Peltier, W. R., Otto-Bliesner, B., Morozova, P. A., McKay, N. P., Lohmann, G., Legrande, A. N., Guo, C., Cao, J., Brady, E., Annan, J. D., and Abe-Ouchi, A.: Large-scale features and evaluation of the PMIP4-CMIP6 midHolocene simulations, Climate of the Past, 16, 1847-1872, https://doi.org/10.5194/cp-16-1847-2020, https://cp.copernicus.org/articles/16/1847/2020/, publisher: Copernicus GmbH, 2020.

Broström, A., Coe, M., Harrison, S. P., Gallimore, R., Kutzbach, J. E., Foley, J., Prentice, I. C., and Behling, P.: Land surface feedbacks and palaeomonsoons in northern Africa, Geophysical Research Letters, 25, 3615-3618, https://doi.org/10.1029/98GL02804, https://agupubs. onlinelibrary.wiley.com/doi/abs/10.1029/98GL02804, 1998.

Brovkin, V., Lorenz, S., Raddatz, T., Ilyina, T., Stemmler, I., Toohey, M., and Claussen, M.: What was the source of the atmospheric CO\&lt;sub\&gt;2\&lt;/sub\&gt; increase during the Holocene?, Biogeosciences, 16, 2543-2555, https://doi.org/10.5194/bg-16-2543-2019, https://bg.copernicus.org/articles/16/2543/2019/, 2019.

Brown, J. R., Brierley, C. M., An, S.-I., Guarino, M.-V., Stevenson, S., Williams, C. J. R., Zhang, Q., Zhao, A., Abe-Ouchi, A., Braconnot, P., Brady, E. C., Chandan, D., D’Agostino, R., Guo, C., LeGrande, A. N., Lohmann, G., Morozova, P. A., Ohgaito, R., O’ishi, R., OttoBliesner, B. L., Peltier, W. R., Shi, X., Sime, L., Volodin, E. M., Zhang, Z., and Zheng, W.: Comparison of past and future simulations of ENSO in CMIP5/PMIP3 and CMIP6/PMIP4 models, Climate of the Past, 16, 1777-1805, https://doi.org/10.5194/cp-16-1777-2020, https://cp.copernicus.org/articles/16/1777/2020/, publisher: Copernicus GmbH, 2020.

Carrington, D. P., Gallimore, R. G., and Kutzbach, J. E.: Climate sensitivity to wetlands and wetland vegetation in mid-Holocene North Africa, Climate Dynamics, 17, 151-157, https://doi.org/10.1007/s003820000099, http://link.springer.com/10.1007/s003820000099, 2001. Chandan, D. and Peltier, W. R.: African Humid Period Precipitation Sustained by Robust Vegetation, Soil, and Lake Feedbacks, Geophysical Research Letters, 47, e2020GL088 728, https://doi.org/https://doi.org/10.1029/2020GL088728, https://agupubs.onlinelibrary.wiley.com/ doi/abs/10.1029/2020GL088728,_eprint: https://agupubs.onlinelibrary.wiley.com/doi/pdf/10.1029/2020GL088728, 2020.

Claussen, M. and Gayler, V.: The Greening of the Sahara during the Mid-Holocene: Results of an Interactive Atmosphere-Biome Model, Global Ecology and Biogeography Letters, 6, 369, https://doi.org/10.2307/2997337, https://www.jstor.org/stable/2997337?origin= crossref, 1997.

Coe, M. T. and Bonan, G. B.: Feedbacks between climate and surface water in northern Africa during the middle Holocene, Journal of Geophysical Research: Atmospheres, 102, 11 087-11 101, https://doi.org/10.1029/97JD00343, http://doi.wiley.com/10.1029/97JD00343, 1997. 
https://doi.org/10.5194/cp-2021-129

Preprint. Discussion started: 5 October 2021

(c) Author(s) 2021. CC BY 4.0 License.

(c) (i)

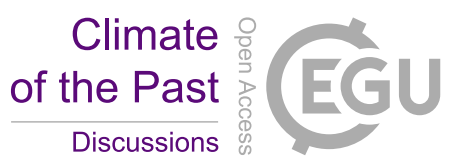

Dallmeyer, A., Claussen, M., Lorenz, S. J., and Shanahan, T.: The end of the African humid period as seen by a transient comprehensive Earth system model simulation of the last 8000 years, Climate of the Past, 16, 117-140, https://doi.org/10.5194/cp-16-117-2020, https: //cp.copernicus.org/articles/16/117/2020/, 2020.

Egerer, S., Claussen, M., and Reick, C.: Rapid increase in simulated North Atlantic dust deposition due to fast change of northwest African landscape during the Holocene, Climate of the Past, 14, 1051-1066, https://doi.org/10.5194/cp-14-1051-2018, https://www.clim-past.net/ 14/1051/2018/, 2018.

Giorgetta, M. A., Brokopf, R., Crueger, T., Esch, M., Fiedler, S., Helmert, J., Hohenegger, C., Kornblueh, L., Köhler, M., Manzini, E., Mauritsen, T., Nam, C., Raddatz, T., Rast, S., Reinert, D., Sakradzija, M., Schmidt, H., Schneck, R., Schnur, R., Silvers, L., Wan, H., Zängl, G., and Stevens, B.: ICON-A, the Atmosphere Component of the ICON Earth System Model: I. Model Description, Journal of Advances in Modeling Earth Systems, 10, 1613-1637, https://doi.org/10.1029/2017MS001242, https://agupubs.onlinelibrary.wiley.com/ doi/abs/10.1029/2017MS001242,_eprint: https://onlinelibrary.wiley.com/doi/pdf/10.1029/2017MS001242, 2018.

Hoelzmann, P., Jolly, D., Harrison, S. P., Laarif, F., Bonnefille, R., and Pachur, H.-J.: Mid-Holocene land-surface conditions in northern Africa and the Arabian Peninsula: A data set for the analysis of biogeophysical feedbacks in the climate system, Global Biogeochemical Cycles, 12, 35-51, https://doi.org/10.1029/97GB02733, https://agupubs.onlinelibrary.wiley.com/doi/abs/10.1029/97GB02733, 1998.

Holmes, J. and Hoelzmann, P.: The Late Pleistocene-Holocene African Humid Period as Evident in Lakes, Oxford Research Encyclopedia of Climate Science, https://doi.org/10.1093/acrefore/9780190228620.013.531, http://oxfordre.com/view/10.1093/acrefore/9780190228620. 001.0001/acrefore-9780190228620-e-531, 2017.

Jungclaus, J., Lorenz, S., Schmidt, H., Brovkin, V., Brüggemann, N., Chegini, F., Gayler, V., Giorgetta, M. A., Gutjahr, O., Haak, H., Hagemann, S., Hanke, M., Ilyina, T., Korn, P., Kröger, J., Linardakis, L., Mehlmann, C., Mikolajewicz, U., Müller, W., Notz, D., Pohlmann, H., Putrasahan, D., Raddatz, T., Ramme, L., Redler, R., Reick, C. H., Riddick, T., Sam, T., Schneck, R., Schnur, R., Schupfner, M., von Storch, J.-S., Wachsmann, F., Wieners, K.-H., Stevens, B., Marotzke, J., and Claussen, M.: The ICON Earth System Model Version 1.0, in preparation.

Kanamitsu, M., Ebisuzaki, W., Woollen, J., Yang, S.-K., Hnilo, J. J., Fiorino, M., and Potter, G. L.: NCEP-DOE AMIP-II Reanalysis (R2), Bulletin of the American Meteorological Society, 83, 1631-1644, https://doi.org/10.1175/BAMS-83-11-1631, https://journals.ametsoc. org/view/journals/bams/83/11/bams-83-11-1631.xml, publisher: American Meteorological Society Section: Bulletin of the American Meteorological Society, 2002.

Krinner, G., Lézine, A.-M., Braconnot, P., Sepulchre, P., Ramstein, G., Grenier, C., and Gouttevin, I.: A reassessment of lake and wetland feedbacks on the North African Holocene climate: FEEDBACKS FROM HOLOCENE SAHARA LAKES, Geophysical Research Letters, 39, n/a-n/a, https://doi.org/10.1029/2012GL050992, http://doi.wiley.com/10.1029/2012GL050992, 2012.

Kutzbach, J., Bonan, G., Foley, J., and Harrison, S. P.: Vegetation and soil feedbacks on the response of the African monsoon to orbital forcing in the early to middle Holocene, Nature, 384, 623-626, https://doi.org/10.1038/384623a0, http://www.nature.com/articles/384623a0, 1996.

Kutzbach, J. E.: Monsoon Climate of the Early Holocene: Climate Experiment with the Earth's Orbital Parameters for 9000 Years Ago, Science, 214, 59-61, https://doi.org/10.1126/science.214.4516.59, https://science.sciencemag.org/content/214/4516/59, 1981.

Levis, S., Bonan, G. B., and Bonfils, C.: Soil feedback drives the mid-Holocene North African monsoon northward in fully coupled CCSM2 simulations with a dynamic vegetation model, Climate Dynamics, 23, 791-802, https://doi.org/10.1007/s00382-004-0477-y, https://link. springer.com/article/10.1007/s00382-004-0477-y, 2004. 
https://doi.org/10.5194/cp-2021-129

Preprint. Discussion started: 5 October 2021

(c) Author(s) 2021. CC BY 4.0 License.

(c) (i)

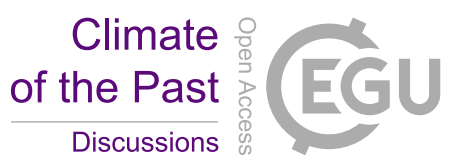

Lézine, A.-M., Hély, C., Grenier, C., Braconnot, P., and Krinner, G.: Sahara and Sahel vulnerability to climate changes, lessons from Holocene hydrological data, Quaternary Science Reviews, 30, 3001-3012, https://doi.org/10.1016/j.quascirev.2011.07.006, http://www. sciencedirect.com/science/article/pii/S0277379111002101, 2011.

Otto, J., Raddatz, T., and Claussen, M.: Strength of forest-albedo feedback in mid-Holocene climate simulations, Climate of the Past, 7 , 1027-1039, https://doi.org/10.5194/cp-7-1027-2011, https://cp.copernicus.org/articles/7/1027/2011/, 2011.

Quade, J., Dente, E., Armon, M., Dor, Y. B., Morin, E., Adam, O., and Enzel, Y.: Megalakes in the Sahara? A Review, Quaternary Research, 90, 253-275, https://doi.org/10.1017/qua.2018.46, https://www.cambridge.org/core/journals/quaternary-research/article/ megalakes-in-the-sahara-a-review/7515BC9AAFE40606D3FC30C9D0C7D9D7, 2018.

Rachmayani, R., Prange, M., and Schulz, M.: North African vegetation-precipitation feedback in early and mid-Holocene climate simulations with CCSM3-DGVM, Clim. Past, p. 11, 2015.

Reick, C. H., Gayler, V., Goll, D., Hagemann, S., Heidkamp, M., Nabel, J. E. M. S., Raddatz, T., Roeckner, E., Schnur, R., and Wilkenskjeld, S.: JSBACH 3 - The land component of the MPI Earth System Model: documentation of version 3.2, p. 4990986, https://doi.org/10.17617/2.3279802, https://pure.mpg.de/pubman/item/item_3279802, artwork Size: 4990986 Medium: application/pdf Publisher: MPI für Meteorologie Version Number: 1, 2021.

Roeckner, E., Bäuml, G., Bonaventura, L., Brokopf, R., Esch, M., Giorgetta, M., Hagemann, S., Kirchner, I., Kornblueh, L., Manzini, E., Rhodin, A., Schlese, U., Schulzweida, U., and Tompkins, A.: The atmospheric general circulation model ECHAM 5. PART I: Model description, https://doi.org/10.17617/2.995269, https://pure.mpg.de/pubman/faces/ViewItemOverviewPage.jsp?itemId=item_995269, publisher: Max-Planck-Institut für Meteorologie, 2003.

Schneck, R., Schnur, R., Reick, C. H., Raddatz, T., and Nabel, J. E.: Evaluation of JSBACH as the land component of Earth System Models, in preparation.

Seager, R., Naik, N., and Vecchi, G. A.: Thermodynamic and Dynamic Mechanisms for Large-Scale Changes in the Hydrological Cycle in Response to Global Warming, Journal of Climate, 23, 4651-4668, https://doi.org/10.1175/2010JCLI3655.1, http://journals.ametsoc.org/ doi/abs/10.1175/2010JCLI3655.1, 2010.

Skinner, C. B. and Poulsen, C. J.: The role of fall season tropical plumes in enhancing Saharan rainfall during the African Humid Period, Geophysical Research Letters, 43, 349-358, https://doi.org/10.1002/2015GL066318, https://agupubs.onlinelibrary.wiley.com/doi/abs/10. 1002/2015GL066318,_eprint: https://onlinelibrary.wiley.com/doi/pdf/10.1002/2015GL066318, 2016.

Tegen, I., Harrison, S. P., Kohfeld, K., Prentice, I. C., Coe, M., and Heimann, M.: Impact of vegetation and preferential source areas on global dust aerosol: Results from a model study, Journal of Geophysical Research: Atmospheres, 107, AAC 14-1-AAC 14-27, https://doi.org/10.1029/2001JD000963, https://agupubs.onlinelibrary.wiley.com/doi/abs/10.1029/2001JD000963, 2002.

Vamborg, F. S. E., Brovkin, V., and Claussen, M.: The effect of a dynamic background albedo scheme on Sahel/Sahara precipitation during the mid-Holocene, Clim. Past, p. 15, 2011.

Zhao, Y., Braconnot, P., Harrison, S. P., Yiou, P., and Marti, O.: Simulated changes in the relationship between tropical ocean temperatures and the western African monsoon during the mid-Holocene, Climate Dynamics, 28, 533-551, https://doi.org/10.1007/s00382-006-0196-7, https://doi.org/10.1007/s00382-006-0196-7, 2007. 